\title{
Association of Succinate Dehydrogenase and Triose Phosphate Isomerase Gene Expression with Intramuscular Fat Content in Loin Muscle of Korean (Hanwoo) Cattle
}

Nam-Kuk Kim ${ }^{1^{+}}$, Seung-Hwan Lee ${ }^{2^{+}}$, Dajeong Lim², Duhak Yoon ${ }^{3}$, Chang-Soo Lee ${ }^{4}$ Oun-Hyun $\mathrm{Kim}^{4} \star$, Hyeong-Cheol $\mathrm{Kim}^{2}$, Sung-Jong $\mathrm{Oh}^{2}$ and Seong-Koo Hong ${ }^{2}$

${ }^{1}$ Gyeongnam Provincial Office, National Agricultural products Quality management Service, Busan 611-804, Korea

${ }^{2}$ National Institute of Animal Science, RDA, Suwon 441-706, Korea

${ }^{3}$ KyungPook National University, Sangju 742-711, Korea

${ }^{4}$ Department of Food Bioscience, Konkuk University, Chungiu 380-701, Korea

Received August 12, 2011 /Revised November 14, 2011 /Accepted December 13, 2011

\begin{abstract}
In a previous study, succinate dehydrogenase (SDH) and triose phosphate isomerase (TPI) were detected by 2D gel electrophoresis as differentially expressed proteins in the longissimus thoracis muscles of cattle aged between 12 and 27 months old. In the present study, we investigated the association of SDH and TPI gene expression with intramuscular fat content in 50 Hanwoo steers. The SDH gene was expressed at a 4 times higher level in the 12 month old group than in the 27 month old group $(p<0.01)$. A regression analysis between gene expression value and intramuscular fat content showed a negative correlation between expression of the SDH gene and intramuscular fat content $(p<0.001)$. In contrast, the expression of the TPI gene showed no significant association with intramuscular fat content. This result suggests that the SDH gene may be a candidate marker gene for intramuscular fat content in the longissimus thoracis of Korean cattle.
\end{abstract}

Key words : Succinate dehydrogenase, triosephosphate isomerase, gene expression, Korean cattle (Hanwoo)

\section{서 론}

한우에 있어서 근내지방(intramuscular fat, 마블링)은 지방 색, 육색, 연도 등에 의해서 결정되며, 이들 요인중 근내지방도 는 소의 육질을 결정하는 주요 요인으로 많은 연구가 수행되 고 있다[9]. 현재, 국내 한우고기 산업에서 근내지방도는 한우 농가의 소득에 미치는 영향이 크기 때문에, 비육농장을 중심 으로 쇠고기의 근내지방 향상을 위하여 비육기간 연장과 같은 사육방식을 택하고 있다. 그러나 장기간의 비육은 근내지방향 상에 도움은 되지만, 등지방 및 내장지방과 같은 불가식지방 량의 증가에 따른 정육율의 감소와 같은 비효율적인 결과를 초래하고 있다[3]. 따라서 근육내 지방을 조절하는 특이 유전 자 및 근육내 지방축적에 대한 유전자발현 메커니즘을 규명할 수 있다면, 효과적인 쇠고기 생산에 이용할 수 있을 것이다.

최근 가축에 있어서 근내지방햠량에 연관된 유전자를 탐색 하기 위하여, QTL (quantitative trait loci) 연구[2,5], 특이발현 유전자 탐색[21], microarray [27] 및 proteomics [8] 등 대량분 석체계를 활용한 다양한 연구기법들이 활용되고 있다[28]. 이

\footnotetext{
†These authors are equally contributed to this work

*Corresponding author

Tel : +82-43-840-3524, Fax : +82-43-851-8331

E-mail : ohk@kku.ac.kr
}

와 더불어, 가축의 경제형질과 연관된 생리·생화학적 경로 등에서 기능이 알려져 있는 유전자를 후보유전자로 선정하여 그의 발현 및 유전변이와 형질과의 연관성을 규명하는 후보유 전자 탐색(candidate gene approach) 연구까지 많은 연구들이 수행되고 있다[14]. Nishimura 등[23]은 일본 흑모화우를 대 상으로 근내지방함량 변화를 분석한 결과 소의 근내지방은 12 개월에서 26 개월 사이에 활발히 증가된다고 보고하였고, $\mathrm{Kim}$ 등[14]은 한우에서 근내지방함량이 27개월령(비육 후기) 에서 12 개월령(비육 전기)보다 8 배 이상 증가됨을 확인하였 다. 또한, $\mathrm{Kim}$ 등[13]은 비육 전 - 후기 등심육을 대상으로 차 등발현단백질 탐색 연구를 수행한 결과, 숙신산탈수소효소 (succinate dehydrogenase, $\mathrm{SDH}$ ) 및 3 탄당인산이성질체화효 소(triosephosphate isomerase, TPI)가 비육후기 감소됨을 확 인하였다. 이러한 연구 결과들은 현재 SNP (single nucleotide polymorphism)를 포함 한 유전자 마커(genetic marker) 개발 에 중요한 자료로 활용되고 있다.

$\mathrm{SDH}$ 는 근육 내에서 숙신산염의 산화작용을 통해 지방분해 를 촉진시킨다고 보고되었으며[22], TPI는 glycerol로부터 생 성되는 dehydroxyacetone phosphate (DHAP)를 glyceraldehydes-3-phosphate로 전환시켜 지방세포 내 중성지방 (triacylglycerol)의 분해작용에 관여하는 것으로 알려져 있다 [11]. 이러한 연구 결과로 볼 때 $\mathrm{SDH}$ 및 TPI가 근육 내 지방생 
합성과 밀접하게 관련되어 있을 것으로 판단된다.

본 연구는 비육 전 · 후기 차등발현을 보이는 두 개의 유전 자(SDH 및 $\mathrm{TPI})$ 가 한우 등심조직내 근내지방함량과 연관성이 있는가를 분석하기 위해서, 근내지방함량 표현형정보를 가지 고 있는 한우 동기우 집단 50 두를 대상으로 유전자발현 분석 을 수행하였다.

\section{재료 및 방법}

\section{공시재료}

$\mathrm{SDH}$ 및 TPI 유전자의 비육 전 - 후기 발현양상 분석을 위하 여 12 개월 및 27 개월령 각 3 두를 공시하였고, 유전자의 발현양 상과 근내지방함량과의 관련성 분석을 위하여 국립축산과학 원에서 동일한 조건으로 사양된 28 30개월령의 동기우 50 두 (체중 $664 \pm 32 \mathrm{~kg}$ )를 분석에 사용하였다. 모든 등심시료는 도축 후 30 분 이내에 채취하여 액체질소를 이용 즉시 동결하고, 사 용 전 까지 $-70^{\circ} \mathrm{C}$ 에 보관하면서 실험에 이용하였으며, 지방함 량 측정은 시료 $1 \mathrm{~g}$ 을 이용 Folch 등[4]의 방법에 기초하여 수행하였다.

\section{총 RNA 추출 및 $\mathrm{CDNA}$ 합성}

등심 육으로부터 총 RNA는 TRIzol을 이용하여 다음과 같 이 진행하였다. 액체질소를 이용하여 곱게 마쇄한 시료 0.1 $\mathrm{g}$ 에 TRIzol reagent $1 \mathrm{ml}$ 를 첨가하여 잘 혼합한 후 10 분간 $13,000 \mathrm{rpm}$ 에서 원심분리한 후 상등액을 취하였다. 얻어진 상 등액에 chloroform $0.2 \mathrm{ml}$ 를 첨가하고 혼합한 후 $13,000 \mathrm{rpm}$ 에서 10 분간 원심분리하여 다시 상등액을 취하고, 상등액에 동량의 isopropanol 첨가 후 원심분리하여 RNA pellet를 획득 하였다. 획득된 RNA pellet은 $70 \%$ 에탄올을 이용하여 세척한 후 건조하고, $\mathrm{DEPC}$ 를 처리한 멸균증류수에 녹여 사용하였다. 유전자 발현분석을 위하여 추출된 총 RNA는 RNeasy MiniElute cleanup kit (Qiagen Co., Ltd., USA)을 이용하여 정제 후 $\mathrm{cDNA}$ 합성에 이용하였다.

조직으로부터 추출된 총 RNA는 유전자 발현분석을 위한 cDNA 합성에 이용하였다. 총 RNA $2 \mu \mathrm{g}$ 에 random primer (Promega, USA) $1 \mu \mathrm{l}, 2.5 \mathrm{mM}$ dNTP $1 \mu \mathrm{l}$ 를 첨가하고, DEPC를 처리한 증류수로 총 $12 \mu \mathrm{l}$ 가 되도록 하였다. $65^{\circ} \mathrm{C}$ 에서 5 분간 변성 후 즉시 얼음 위에서 냉각한 후 $5 \times$ buffer $4 \mu \mathrm{l}, 0.1 \mathrm{M}$ DTT $2 \mu l$, RNase inhibitor (Promega) 0.5U 및 reverse transcriptase (SuperScript II Reverse Transcriptase, Invitrogen, USA) $1 \mu 1$ 를 첨가하여 $42^{\circ} \mathrm{C}$ 에서 60 분간 반응시킨 후, $70^{\circ} \mathrm{C}$ 에 서 15 분간 반응시켜 reverse transcriptase를 불활성화 시킨 후 real-time PCR의 주형으로 사용하였다.

Real-time PCR을 통한 유전자 발현분석

유전자의 발현양상을 분석하기 위하여 Real-time RT-PCR
법을 이용하였다. 시료로부터 추출된 총 RNA를 이용하여 $\mathrm{cDNA}$ 를 합성하고, 합성된 $\mathrm{cDNA} 0.2 \mu \mathrm{g}$ 을 주형으로 $2 \mathrm{X}$ Power SYBR Green PCR Master mix (Applied Biosystems, $\mathrm{UK}$ )와 각각의 primer set을 이용하여 7500 Real time PCR system (Applied Biosystems)을 통하여 분석하였다. $\mathrm{SDH}$ (5'-TCCTGCAGACCCGGAGATAAAGTT- ${ }^{\prime}{ }^{\prime}, 5^{\prime}$-TCGCAGTT CCGATGTCCTTATGCT-3') 및 TPI (5'-AACAGGCCCAGG AAGTACACGAAA- $3^{\prime}, 5^{\prime}$-TCAACGAACTCAGGCTTGAGG GAA-3')유전자 분석에 사용된 primer는 GenBank에 등록된 염기서열(NM_174178, NM_001013589.2)을 기준으로 제작되 었다. 각 $\mathrm{PCR}$ 반응은 $95^{\circ} \mathrm{C}$ 에서 10 분간 예비 변성한 후 $95^{\circ} \mathrm{C}$ 에 서 15 초, $60^{\circ} \mathrm{C}$ 에서 1 분간 40 회 반복하여 수행하였다. $\mathrm{PCR}$ 반응 종결 후 melting curve 작성을 통하여 유전자 증폭의 정확성을 재확인하였다. 유전자 발현량의 내부 보정을 위하여 Genbank 에 등록된(BC102589) house keeping 유전자인 GAPDH (glyceraldehyde-3-phosphate dehydrogenase)를 이용하였고, 유전자 발현량은 2- $\Delta \mathrm{Ct}$ 값을 이용하여 계산하였다. 내부 보정 용 유전자로 사용된 GAPDH유전자의 발현은 $5^{\prime}$-GGGTCA TCATCTCTGCACCT- $3^{\prime}$ 와 $5^{\prime}$-GGTCATAAGTCCCTCCAC GA-3'의 primer를 이용하여 분석하였고, 발현량 $(\mathrm{Ct})$ 은 25 26 의 범위로 각 개체별 유사한 값을 가짐을 확인 후 사용하였다.

\section{통계분석}

유전자의 발현량이 근내지방함량에 미치는 영향을 분석을 위하여 R statistical program의 ANOVA (analysis of variance) 모델을 활용하여 분석하였고, 분석에 사용한 모형은 다 음과 같다.

Fat $_{\mathrm{i}}=\mu+$ Expression $_{\mathrm{j}}+\mathrm{Age}_{\mathrm{ij}}+\mathrm{e}_{\mathrm{ij}}$

여기서, $\mathrm{Fat}_{\mathrm{i}}$ 는 근내지방함량, $\mu$ 는 전체 평균, Expression;은 각 유전자의 발현량(2- $\Delta \mathrm{Ct}), \mathrm{Age}_{\mathrm{ij}}$ 는 도축연령(개월) 및 $\mathrm{e}_{\mathrm{ij}}$ 는 임의의 오차를 나타낸다.

\section{결과 및 고찰}

본 연구는 succinate dehydrogenase (SDH) 및 triosephosphate isomerase (TPI) 유전자를 대상으로 유전자발 현이 한우 근내지방함량과 미치는 영향을 분석하였다. 소의 성장 및 비육에 있어서 비육전기에 해당하는 12 개월령과, 비 육 후기에 해당하는 27 개월령에 있어서 소의 근내지방은 최고 로 증가한다고 보고되어 있다[23]. 이러한 생리학적 특성을 고 려하여, 비육 전 - 후기 시료를 대상으로 유전자 발현분석을 수행한 결과 SDH 유전자는 비육전기(12개월령)에서 비육후 기(27개월령)보다 4 배 발현이 높은 것으로 확인되었다 $(p<0.01)$. 그러나 TPI 유전자의 경우 발현량의 차이를 보이지 않았다(Fig. 1, Table 1). 소에 있어서 12개월과 27개월령은 근 


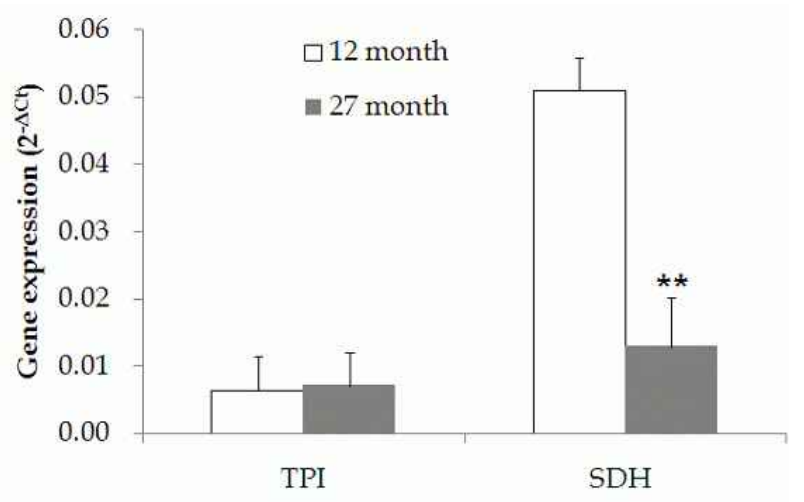

Fig. 1. Gene expression level of succinate dehydrogenase (SDH) and triosephosphate isomerase (TPI) genes using real-time PCR in Korean cattle (Hanwoo) loin muscle between 12 and 27 month old groups. ${ }^{* *} p<0.01$

Table 1. Least square mean $( \pm \mathrm{SE})$ of SDH and TPI gene between 12 and 27 month old group

\begin{tabular}{lccc}
\hline Gene & 12 month & 27 month & P value \\
\hline SDH & $0.051( \pm 0.008)$ & $0.013( \pm 0.008)$ & 0.005 \\
TPI & $0.006( \pm 0.002)$ & $0.007( \pm 0.002)$ & 0.761 \\
\hline
\end{tabular}

내지방 뿐만 아니라, 성장에 있어서도 급격하게 증가하기 때 문에, 이 시기에 있어서 차등발현되는 유전자가 한우에 있어 서 근내지방함량축적과 연관성이 있는지를 규명하기 위해서, 한우 동기우 집단 50 두의 등심육을 대상으로 유전자 발현량과
근내지방함량과의 관련성을 분석하였다. 그 결과 $\mathrm{SDH}$ 유전자 가 근내지방함량과 고도의 유의적 $(p<0.001)$ 관계가 있음을 확 인하였다(Fig. 2, Table 2).

Pertick 등[24]의 연구에 따르면 근육 내 지방의 축적은 지방 의 합성(synthesis)과 $\beta$-oxidation에 의한 분해(catabolism)작 용의 균형에 의해 이뤄지며, 분해작용의 감소는 근육 내 지방 축적과 관련되어 있다고 보고하였다. 최근 Lee 등[20]의 microarray 분석을 활용한 근내지방도에 따른 한우 등심 내 차등 발현 유전자 발굴 실험에 따르면 $\mathrm{ADAM}$ metallopeptidase with thrombospondin type 1 motif, 4 (ADAMTS4) 및 squalene epoxidase (SQLE) 등 단백질 분해와 cholesterol 생합성 에 관여하는 유전자들의 발현이 차이를 보이는 것으로 확인 되었다. 또한, 유리지방산이 근육 및 지방세포로 이동되는데 관여하는 adipose fatty acid binding protein (FABP4) [10] 및 포화지방산을 불포화지방산으로 전환시켜주는 stearoyl-CoA desaturase $(\mathrm{SCD})$ 등의 발현이 근내지방함량과 밀접히 관련되 어 있음이 보고되었다[1]. 이러한 연구 결과는 근육 내 지방축 적이 지방 및 에너지 대사에 관여된 유전자들과 밀접히 관련 되어 있음을 잘 설명하고 있다.

Succinate dehydrogenase (SDH) 및 triosephosphate isomerase (TPI)는 세포 내에서 분해작용(catabolic metabolism) 에 관여하는 유전자로, Krebs cycle [26] 및 glycolytic pathway [11]에 속해있다. TPI유전자는 중성지방 합성의 전구체 로 사용되는 dihydroxyacetone phosphate (DHAP)를 glycer-
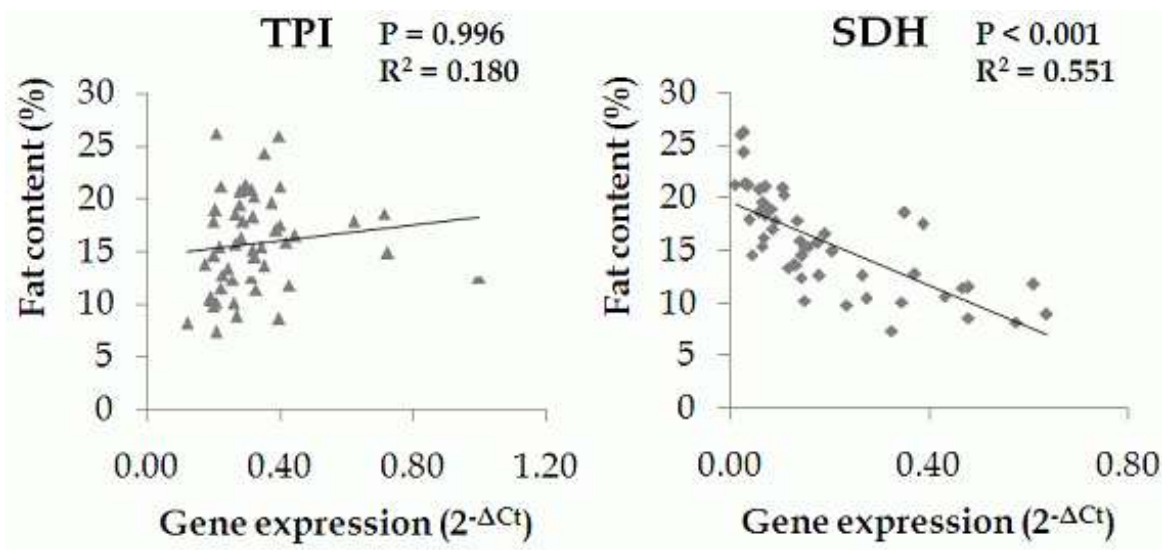

Fig. 2. Regression analysis between intramuscular fat content (\%) and expression level (x-axis) from real-time PCR for each sample.

Table 2. ANOVA table of SDH and TPI gene expression analysis in loin muscles

\begin{tabular}{lccccc}
\hline Source & Df & Sum Sq & Mean Sq & F value & $\operatorname{Pr}(>\mathrm{F})$ \\
\hline SDH & 1 & 538.35 & 538.35 & 55.9842 & $1.524 \mathrm{e}-09^{* * *}$ \\
Age & 1 & 58.3 & 58.3 & 6.0625 & $0.01753^{*}$ \\
Residuals & 47 & 451.96 & 9.62 & & 0.9319 \\
\hline TPI & 1 & 16.37 & 16.368 & 11.7725 & $0.001262^{* *}$ \\
Age & 1 & 206.76 & 206.764 & & \\
Residuals & 47 & 825.48 & 17.563 & & \\
\hline
\end{tabular}


aldehyde 3-phosphate로 전환시키는데 관여하고 있다. Laville 등[19]은 연도가 높은 근육 내 TPI 발현이 더 높았으며, 이는 지방함량과 관련되어 있다고 설명하였으며, Kim 등[12] 은 지방축적이 증가되는 성장단계 시료에서 지속적으로 TPI 의 발현이 증가된다고 보고하였다. 또한, 지방세포(3T3-L1)를 이용한 지방분화(adipogenesis)유도 실험에서 TPI유전자의 발현이 지방분화과정 중 증가되는 현상을 보였으나, 지방분화 초기에 관여한다고 보고하였다[16]. 본 실험에서도 TPI가 근내 지방함량이 증가되면서 발현이 증가됨을 확인하였으나 유의 적인 차이는 관찰하지 못하였으며, 소 조직유래 지방 전구세 포를 이용한 지방분화유도 실험에서 TPI의 발현이 단백질 수 준에서 감소된다고 보고된 바도 있어[25], 앞으로 다양한 시료 의 분석 및 발현유도 실험 등을 통해 TPI유전자 발현과 근내지 방함량과의 관계를 명확히 구명할 필요성이 있을 것으로 판단 된다.

근내지방함량과 고도의 통계적 유의성을 보인 $\mathrm{SDH}$ 는 미토 콘드리아 내 Krebs cycle에 관여하는 유전자로, succinate를 산화(oxidation)과정을 통해 fumarate로 전환시키는 역할을 담당하고 있다. Lai와 Goldman [18]의 지방분화(adipocytes differentiation) 유도에 따른 유기산(organic acid) 변화 실험 에 따르면 succinate, malate 등의 유기산이 분화과정 중 10 배 이상 증가되는 것을 확인하였으며, 이러한 결과는 에너지 대 사에 관여하는 미토콘드리아의 활성이 지방분화 과정 중 감소 되어, succinate를 fumarate로 충분히 전환시키지 못하기 때문 이라고 보고하였다. Zhu 등[29]은 SDHD (succinate dehydrogenase, subunit D)의 147번째 아미노산을 형성하는 유 전자 내 변이가 등심단면적(loin muscle area)과 연관이 있음 을 보고하였고, Habano 등[6]도 SDH 유전자의 변이는 미토콘 드리아의 대사기능에 영향을 미친다고 보고하였다. 최근, 지 방함량의 차이를 보이는 돼지품종을 대상으로 단백체 (proteome) 및 전사체(transcriptome)연구를 통해 $\mathrm{SDH}$ 가 차 등발현됨을 확인하였다[15,22]. 또한 소 유래 mesenchymal stem cells (MSCs)의 지방분화유도 실험에서도 $\mathrm{SDH}$ 유전자의 발현이 지속적으로 감소되는 경향을 관찰하였으며[20], 본 연 구에서도 비육 전·후기 시료 및 동기우 집단 50 두를 대상으 로 유전자발현 및 통계분석을 통해 $\mathrm{SDH}$ 유전자가 근내지방과 고도의 유의성이 있음이 확인되었다. 이러한 결과는 $\mathrm{SDH}$ 유 전자가 한우 등심 내 근내지방함량을 설명할 수 있는 유용한 마커라고 생각된다.

\section{References}

1. Canovas, A., J. Estany, M. Tor, R. N. Pena, and O. Doran. 2009. Acetyl-CoA carboxylase and stearoyl-CoA desaturase protein expression in subcutaneous adipose tissue is reduced in pigs selected for decreased backfat thickness at constant intramuscular fat content. J. Anim Sci. 87,
3905-3914.

2. Casas, E., J. W. Keele, S. D. Shackelford, M. Koohmaraie, and R. T. Stone. 2003. Identification of quantitative trait loci for growth and carcass composition in cattle. Anim Genet. 35, 2-6.

3. Childs, K. D., D. W. Goad, M. F. Allan, D. Pomp, C. Krehbiel, R. D. Geisert, J. B. Morgan, and J. R. Malayer. 2002. Differential expression of NAT1 translational repressor during development of bovine intramuscular adipocytes. Physiol. Genomics 10, 49-56.

4. Folch, J., M. Lees, and G. H. S. Stanley. 1957. A simple method for isolation and purification of total lipids from animal tissues. J. Biol. Chem 226, 497-508.

5. Gutierrez-Gil, B., P. Wiener, G. R. Nute, D. Burton, J. L. Gill, J. D. Wood, and J. L. Williams. 2007. Detection of quantitative trait loci for meat quality traits in cattle. Anim Genet. 39, 51-61.

6. Habano, W., T. Sugai, S. Nakamura, N. Uesugi, T. Higuchi, M. Terashima, and S. Horiuchi. 2003. Reduced expression and loss of heterozygosity of the SDHD gene in colorectal and gastric cancer. Oncol. Rep. 10, 1375-1380.

7. Hirwa, C. A., P. Wallace, X. Shen, Q. Nie, G. Yang, and X. Zhang. 2011. Genes related to economically import traits in beef cattle. Asian J. Anim Sci. 5, 34-45.

8. Hollung, K., E. Veiseth, X. Jia, E. M. Færgestad, and K. I. Hildrum. 2007. Application of proteomics to understand the molecular mechanisms behind meat quality. Meat Sci. 77, 97-104.

9. Hovenier, R., E. Kanis, T. Van Asseldink, and N. G. Westerink, 1993. Breeding for pig meat quality in halothane negative populations-a review. Pig News Inform 14, $17 \mathrm{~N}-35 \mathrm{~N}$.

10. Jurie, C., I. Cassar-Malek, M. Bonnet, C. Leroux, D. Bauchart, P. Boulesteix, D. W. Pethick, and J. F. Hocquette. 2007. Adipocyte fatty acid-binding protein and mitochondrial enzyme activities in muscles as relevant indicators of marbling in cattle. J. Anim Sci. 85, 2660-2669.

11. Kalhan, S. C., S. Mahajan, E. Burkett, L. Reshef, and R. W. Hanson. 2001. Glyceroneogenesis and the source of glycerol for hepatic triacylglycerol synthesis in human. J. Biol. Chem 276, 12928-12931.

12. Kim, N. K., J. H. Lim, M. J. Song, O. H. Kim, B. Y. Park, M. J. Kim, I, H, Hwang, and C. S. Lee. 2007. Developmental proteomic profiling of porcine skeletal muscle during postnatal development. Asian-Aust. J. Anim Sci. 20, 1612-1617.

13. Kim, N. K., S. H. Lee, Y. M. Cho, E. S. Son, K. Y. Kim, C. S. Lee, D. Yoon, S. K. Im, S. J. Oh, and E. W. Park. 2009. Proteome analysis of the $\mathrm{m}$. longissimus dorsi between fattening stages in Hanwoo steer. BMB 42, 433-438.

14. Kim, N. K., S. K. Kim, K. N. Heo, D. Yoon, C. S. Lee, S. K. Im, and E. W. Park. 2008. Expression profiles of triacylglycerol biosynthesis genes on fattening stages in Hanwoo. J. Anim Sci. Technol. 50, 293-300.

15. Kim, N. K., H. R. Park, E. S. Son, Y. S. Kim, S. R. Kim, and C. S. Lee. 2010. Comparative studies of skeletal muscle proteome and transcriptome profilings between pig breeds. 
Mamm Genome 21, 307-319.

16. Kim, S. J., K. H. Lee, Y. S. Lee, E. G. Mun, D. Y. Kwon, and Y. S. Cha. 2007. Transcriptome analysis and promoter sequence studies on early adipogenesis in 3T3-L1 cells. Nutr. Res. Prac. 1, 19-28.

17. Kim, S. K., N. K. Kim, D. Yoon, T. H. Kim, B. K. Yang, and H. J. Lee. 2010. Gene expression of candidate genes involved in fat metabolism during in vitro adipogenic differentiation of bovine mesenchymal stem cell. J. Anim Sci. Technol. 52, 265-270.

18. Lai, R. K. and P. Glodman. 1992. Organic acid profiling in adipocyte differentiation of 3T3-F442A cells: increased production of Krebs cycle acid metabolites. Metabolism 41, 545-547.

19. Laville, E., T. Sayd, C. Terlouw, C. Chambon, M. Damon, C. Larzul, P. Leroy, J. Glenisson, and P. Cherel. 2007. Comparison of sarcoplasmic proteomes between two groups of pig muscles selected for shear force of cooked meat. J. Agric. Food Chem 55, 5834-5841.

20. Lee, S. H., C. Gondro, J. Werf, N. K. Kim, D. Lim, E. W. Park, S. J. Oh, J. P. Gibson, and J. M. Thompson. 2010. Use of a bovine genome array to identify new biological pathways for beef marbling in Hanwoo (Korean Cattle). BMC Genomics 11, 623.

21. Lee, S. H., E. W. Park, Y. M. Cho, S. K. Kim, J. H. Lee, J. T. Jeon, C. S. Lee, S. K. Im, S. J. Oh, J. M. Thompson, and D. Yoon. 2007. Identification of differentially expressed genes related to intramuscular fat development in the early and late fattening stages of hanwoo steers. J. Biochem $\mathrm{Mol}$. Biol. 40, 757-764.

22. Liu, J., M. Damon, N. Guitton, I. Guisle, P. Ecolan, A.
Vincent, P. Cherel, and F. Gondret. 2009. Differentially-expressed genes in pig pongissimus muscles with contrasting levels of fat, as identified by combined transcriptomic, reverse transcription PCR, and proteomic analyses. J. Agric. Food Chem 57, 3808-3817.

23. Nishimura, T., A. Hattori, and K. Takahashi. 1999. Structural changes in intramuscular connective tissue during the fattening of Japanese black cattle: effect of marbling on beef tenderization. J. Anim Sci. 77, 93-104.

24. Pethick, D. W., D. N. D’Souza, F. R. Dunshea, and G. S. Harper. 2005. Fat metabolism and regional distribution in ruminants and pig-influences of genetics and nutrition. Rec. Adv. Anim Nutr. 15, 39-45.

25. Rajesh, R. V., G. N. Heo, M. R. Park, J. S. Nam, N. K. Kim, D. Yoon, T. H. Kim, and H. J. Lee. 2010. Proteomic analysis of bovine omental, subcutaneous and intramuscular preadipocytes during in vitro adipogenic differentiation. Comp. Biochem Physiol. D, 5, 234-244.

26. Scheffler, I. E. 1998. Molecular genetics of succinate: quinine oxidoreductase in eukaryotes. Prog. Nucleic Acid Res. Mol. Biol. 60, 267-315.

27. Wang, Y. H., A. Reverter, S. H. Tan, N. D. Jager, R. Eang, S. M. McWilliam, L. M. Cafe, P. L. Greenwood, and S. A. Lehnert. 2008. Gene expression patterns during intramuscular fat development in cattle. J. Ainm Sci. 87, 119-130.

28. Yu, S. L. and J. H. Lee. 2006. Current research status for economically important candidate genes and microarray studies in cattle. J. Anim Sci. Technol. 48, 169-190.

29. Zhu, Z. M., J. B. Zhang, and S. H. Zhao. 2005. Cloning, mapping and association study with carcass traits of the porcine SDHD gene. Anim Genet. 36, 191-195.

\section{초록 : 한우 등심조직 내 succinate dehydrogenase 및 triosephosphate isomerase 발현이 근내 지방함량에 미치는 영향에 관한 연구 \\ 김남국 $^{{ }^{\dagger}} \cdot$ 이승환 ${ }^{2 \dagger} \cdot$ 임다정 ${ }^{2} \cdot$ 윤두학 $^{3} \cdot$ 이창수 ${ }^{4} \cdot{\text { 김언현 }{ }^{4}{ }^{*} \cdot \text { 김형철 }^{2} \cdot \text { 오성종 }}^{2} \cdot$ 홍성구 $^{2}$ \\ ( ${ }^{1}$ 국립농산물품질관리원, ${ }^{2}$ 국립축산과학원, ${ }^{3}$ 경북대학교, ${ }^{4}$ 건국대학교)}

비육 전(12개월령) · 후(27개월령)기 한우 등심육을 대상으로 단백체 연구를 통하여 succinate dehydrogenase (SDH) 및 triosephosphate isomerase (TPI) 단백질의 발현 차이가 관찰되었다. 따라서 본 연구는 근내지방함량의 차이를 보이는 비육 전·후기 한우 등심육 내 차등발현을 보이는 $\mathrm{SDH}$ 및 TPI 유전자를 대상으로 근내지방함량 과의 관련성 규명을 위하여, 비육 전 - 후기 및 한우 동기우 집단 50 두를 대상으로 유전자 발현분석 및 통계분석 을 수행하였다. 비육 전 · 후기 시료를 대상으로 유전자 발현분석을 수행한 결과 SDH 유전자는 12 개월령에서 27 개월령보다 4 배 발현이 높은 것으로 확인되었으며, 한우 동기우 집단 50 두 등심육을 대상으로 유전자 발현량과 근내지방함량과의 관련성을 분석한 결과에서도 근내지방함량과 고도의 통계적 유의성 $(p \times 0.001)$ 이 있음을 확인하 였다. 그러나 TPI의 경우 근내지방함량과의 관련성은 확인되지 않았다. 이러한 결과로 볼 때 SDH 유전자는 한우 등심육 내에서 근내지방함량과 관련된 유전자로 판단되며, 지속적으로 유전자구조 변이연구 등을 통한 유전자 마커로의 개발이 필요할 것으로 생각된다. 